\title{
TRIBAL WOMEN PARTICIPATION IN AGRICULTURE AND ALLIED SECTORS IN GARIABAND DISTRICT OF CHHATTISGARH
}

\author{
Bebika Dhruw ${ }^{*}{ }^{\circledR}$ (iD, Reshma Kaushal 2 , Rohit Bhagat 3 , Narottam Atree 4 \\ ${ }^{* 1,2,3,4}$ Research Scholar, Department of Agricultural Economics, Indira Gandhi Krishi \\ Vishwavidyalaya, Raipur, Chhattisgarh, India
}

DOI: https://doi.org/10.29121/granthaalayah.v8.i9.2020.1225

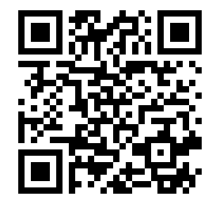

Article Type: Research Article

Article Citation: Bebika Dhruw, Reshma Kaushal, Rohit Bhagat, and Narottam Atree. (2020). TRIBAL WOMEN PARTICIPATION IN

AGRICULTURE AND ALLIED SECTORS IN GARIABAND DISTRICT OF CHHATTISGARH. International Journal of Research -

GRANTHAALAYAH, 8(9), 334-344. https://doi.org/10.29121/granthaa layah.v8.i9.2020.1225

Received Date: 19 August 2020

Accepted Date: 30 September 2020

Keywords:

Tribal Women

Participation

Agriculture

\section{ABSTRACT}

Agriculture is the most important and significant part of our life. It plays a vital role in Indian economy. Farm women's are backbone of Indian agriculture. Present study was conducted at Teka and Kopra villages of Fingeshwar block, Gariaband district, Chhattisgarh. The aim of study is to ascertain the participation rate of tribal women of farm, wage discrimination, and constraints faced. A sample size of 150 households seventy-five each from two village viz. Teka and Kopra through random sampling method. The data was collected through structured interview schedule. Findings of the study that the per year participation of tribal households in different operations of farm were 250.07 man-days on an overall basis. Participation rate of tribal women in agriculture and allied sectors is high as compared to their male counterparts. The study revealed that the difference in wages of female and male wages was found to be much lower than the government wage rate. Major constraints of tribal women in the study area was low wages, less awareness on developmental programmes, lack of education, lack of freedom to take decision, health issues etc. there is need to put more attention on awareness programmes government schemes of scheduled tribes by the extension services.

\section{INTRODUCTION}

A social group is usually identified by a common territory, dialect and cultural homogeneity, social and political organization. It may include several sub groups. Generally, tribe becomes Scheduled Tribe only when it is notified as Scheduled Tribe under Article 342 of Constitution of India. Agriculture is one such area where the developmental activities can be planned for the tribal farm women. Modern agricultural technology is almost unknown to the tribal community and has been left out from the main stream of economic development (Shamna et al., 2018). The rural women are extensively involved in agricultural activities. The nature and extent of their involvement differs with the variations in agro production systems. The way of participation of female in agricultural production varies with landowning status of farm households. Their roles ranges are from managers to landless labourers (Vinod Kumar et al., 1985). Tribal farm women play an important role and make significant contribution to small and medium sized farm (Mohanta, 2017). Tribal women engaged at about 90 per cent in agricultural activities. The present study present study has taken up following objectives:

1) To analyse the participation of tribal women in different operations of farm.

2) To examine the wages of tribal women in agriculture \& allied sector.

(C) 2020 The Author(s). This is an open access article distributed under the terms of the Creative Commons Attribution License, which permits unrestricted use, distribution, and reproduction in any medium, provided the original author and source are credited. 
Tribal Women Participation in Agriculture and Allied Sectors in Gariaband District of Chhattisgarh

3) To study the constraints faced by tribal women workers in the study area and to Suggest some suitable measure for the same.

\section{MATERIALS AND METHODS}

The study was conducted in Teka and Kopra villages the area in Fingeshwar block of Gariaband district, Chhattisgarh. The villages Teka and Kopra were selected randomly \& purposively selected the district Gariaband and block Fingeshwar through maximum no. of tribal female population. The total size of sample consists of 150 tribal household, seventy five households each from two villages were selected. Primary data was collected through structured personal interview and secondary data was collected through various books, journals and websites. The data are analyzed and tabulated by using of percentage and the total time spent converted into man-days. The results are discussed in the following tables.

\section{RESULTS AND DISCUSSIONS}

The results discuss about the participation rate in different activities of farm, wage discrimination and constraints faced by tribal women.

Table 1: General profile of respondent Tribal

\begin{tabular}{|c|c|c|c|c|}
\hline S. No. & Particulars & Category & Respondents in No. & Respondents in Per cent \\
\hline \multirow[t]{4}{*}{1.} & \multirow[t]{4}{*}{ No. of respondents } & Landless & 6 & 4.00 \\
\hline & & Marginal & 103 & 68.67 \\
\hline & & Small & 32 & 21.34 \\
\hline & & Medium & 9 & 6.00 \\
\hline \multirow[t]{4}{*}{2.} & \multirow[t]{4}{*}{ Total family member } & Landless & 26 & 3.87 \\
\hline & & Marginal & 465 & 69.29 \\
\hline & & Small & 143 & 21.31 \\
\hline & & Medium & 37 & 5.51 \\
\hline \multirow[t]{4}{*}{3.} & Working member & Landless & 15 & 2.20 \\
\hline & & Marginal & 247 & 36.81 \\
\hline & & Small & 82 & 12.22 \\
\hline & & Medium & 21 & 3.1 \\
\hline \multirow[t]{4}{*}{4.} & Total family size & Land less & 4.3 & - \\
\hline & & Marginal & 4.5 & - \\
\hline & & Small & 4.4 & - \\
\hline & & Medium & 4.1 & - \\
\hline \multirow[t]{4}{*}{5.} & Total Land holding & Landless & 0 & - \\
\hline & & Marginal & 0.43 & - \\
\hline & & Small & 1.16 & - \\
\hline & & Medium & 2.27 & - \\
\hline \multirow[t]{4}{*}{6.} & Education & Illiterate & 58 & 38.67 \\
\hline & & Primary education & 69 & 46.00 \\
\hline & & Secondary education & 21 & 14.00 \\
\hline & & Graduate & 2 & 1.33 \\
\hline 7. & Literacy rate & & - & 73.20 \\
\hline \multirow[t]{3}{*}{8.} & Age & Young $<30$ & 23 & 15.33 \\
\hline & & Middle 30 to 50 & 109 & 72.67 \\
\hline & & Old $>50$ & 18 & 12.00 \\
\hline
\end{tabular}

Source: Primary data 


\subsection{PARTICIPATION OF TRIBAL WOMEN IN DIFFERENT OPERATIONS OF FARM}

It was observed in Table 2 that the participation of tribal was 189.90 man-days per year, on an overall basis. The highest man-days found in marginal i.e. 244.48 man- days per year. In agricultural operations, the highest manday was seen in transplanting i.e. 46.85 man-days per year. The women labourers got on 127.96 man-days of employment in a year in agriculture in Chhattisgarh State (Jaiswal, 2018). The tribal women earned on an average 158 days of work per year on farm (Naresh, 2014). In transplanting highest man-days was found in small farmers i.e. 59.39 man-days per year. Jaiswal (2018) reported that the total no. of man-days per year involved in agriculture was highest in transplanting which are 24.75 man-days per year. Shaman et al. (2018) reported that the total mandays in rice, jute and mustard cultivation in terms of man-days in different operations were 379.2, 280.4 and 472.4 man-days per year respectively.

Table 2: Per household employment in Agriculture (man-days)

\begin{tabular}{|c|c|c|c|c|c|}
\hline Operations & Landless & Marginal & Small & Medium & Overall \\
\hline Field Preparation & 4.51 & 10.44 & 10.76 & 12.27 & 9.49 \\
\hline Sowing & 1.07 & 5.16 & 7.26 & 8.3 & 5.45 \\
\hline Transplanting & 21.37 & 56.89 & 59.39 & 49.77 & 46.85 \\
\hline Irrigation & 2.43 & 2.70 & 1.93 & 1.32 & 2.09 \\
\hline Weeding & 28.75 & 68.00 & 51.3 & 37.79 & 46.46 \\
\hline Fertilizer/Manure/Plant Protection & 0.63 & 4.78 & 2.89 & 4.27 & 3.14 \\
\hline Harvesting & 34.12 & 59.28 & 50.81 & 39.17 & 45.84 \\
\hline Threshing & 1.04 & 5.16 & 5.54 & 4.9 & 4.16 \\
\hline Winnowing & 1.15 & 6.44 & 3.81 & 4.5 & 3.97 \\
\hline Grading \& Packaging & 1.78 & 5.44 & 9.39 & 8.06 & 6.17 \\
\hline Transport (Loading \& Unloading) & 2.65 & 13.54 & 16.88 & 8.65 & 10.43 \\
\hline Marketing & 3.51 & 6.65 & 8.38 & 7.66 & 6.55 \\
\hline Total & 103.01 & 244.48 & 225.45 & 186.66 & 189.90 \\
\hline
\end{tabular}

Source: Primary data

Table 3 revealed that the participation of tribal women in agriculture was 56.62 per cent. Among all the agricultural operations the highest participation of tribal women was found in transplanting that's holding rank $1^{\text {st }}$ with 97.87 per cent participation followed by weeding, harvesting, grading \& packaging, winnowing, sowing, having rank II, III, IV, V, VI, respectively. Less involvement in irrigation, threshing, marketing, fertilizer/manure/plant protection measures, field preparation having rank VII, VIII, IX, X, XI and they do not involved in transports (loading and unloading) having rank XII. The results are in line with the findings of Mohanta (2018).

Table 3: Participation Rate of Tribal women in Agriculture operations

\begin{tabular}{|c|c|c|}
\hline Operations & Per cent & Rank \\
\hline Transplanting & 97.87 & $\mathrm{I}$ \\
\hline Weeding & 95.74 & II \\
\hline Harvesting & 93.34 & III \\
\hline Grading \& Packaging & 62.23 & IV \\
\hline Winnowing & 51.12 & V \\
\hline Sowing & 44.45 & VI \\
\hline Irrigation & 24.45 & VII \\
\hline Threshing & 22.23 & VIII \\
\hline Marketing & 20.00 & IX \\
\hline Fertilizer/Manure/Plant Protection measures & 11.12 & $\mathrm{X}$ \\
\hline Field Preparation & 6.66 & $\mathrm{XI}$ \\
\hline Transport (Loading \& Unloading) & 0.00 & $\mathrm{XII}$ \\
\hline Total & 56.62 & - \\
\hline
\end{tabular}

Source: Primary data 


\subsection{PER HOUSEHOLD EMPLOYMENT DETAILS IN KITCHEN GARDENING/VEGETABLE CULTIVATION}

Table 4 shows that highest total number of man-days per year contributed in vegetable production was observed in harvesting (3.56) followed by transplanting (3.40). Least man-days observed in grading 0.57 man-days per year.

Table 4: Per household employment in Kitchen gardening/Vegetable cultivation (man-days)

\begin{tabular}{|c|c|c|c|c|c|}
\hline Operations & Landless & Marginal & Small & Medium & Overall \\
\hline Nursery preparation & 0.78 & 1.32 & 1.54 & 1.73 & 1.34 \\
\hline Field preparation & 0.32 & 1.21 & 2.13 & 2.55 & 1.55 \\
\hline Sowing & 0.12 & 1.78 & 1.83 & 2.71 & 1.61 \\
\hline Transplanting & 1.78 & 2.76 & 4.93 & 4.15 & 3.40 \\
\hline Irrigation & 0.11 & 0.54 & 0.82 & 0.97 & 0.61 \\
\hline Fertilizer/Manure/Plant protection & 0.2 & 0.29 & 0.86 & 0.98 & 0.58 \\
\hline Intercultural operation & 1.63 & 2.78 & 3.07 & 3.94 & 2.85 \\
\hline Harvesting & 1.43 & 3.79 & 4.38 & 4.64 & 3.56 \\
\hline Grading & 0.27 & 0.53 & 0.64 & 0.86 & 0.57 \\
\hline Transport (loading \& unloading) & 0.73 & 0.84 & 1.49 & 1.23 & 1.07 \\
\hline Marketing & 0.19 & 2.26 & 4.2 & 4.31 & 2.74 \\
\hline Total & 7.56 & 18.1 & 25.89 & 28.07 & 19.90 \\
\hline
\end{tabular}

Source: Primary data

Table 5: Participation rate of tribal women in Kitchen gardening/vegetable cultivation

\begin{tabular}{|c|c|}
\hline Operation & Per cent \\
\hline Nursery preparation & 100 \\
\hline Field preparation & 68.89 \\
\hline Sowing & 86.67 \\
\hline Transplanting & 100 \\
\hline Irrigation & 53.33 \\
\hline Weeding & 91.11 \\
\hline Intercultural operation & 93.33 \\
\hline Harvesting & 100 \\
\hline Grading & 46.67 \\
\hline Transport (loading \& unloading) & 28.89 \\
\hline Marketing & 64.44 \\
\hline Total & 77.96 \\
\hline
\end{tabular}

Source: Primary data

Table 5 is depicts that the total percentage participation of tribal women among the kitchen gardening/vegetable cultivation is 77.96 per cent. Contribution of tribal women is highest in nursery preparation, transplanting and harvesting which accounts 100 per cent. Least participation of tribal women in transport (loading \& unloading) 28.89 per cent and fertilizer/manure/plant protection measures 40 per cent.

\subsection{PER HOUSEHOLD EMPLOYMENT DETAILS IN DAIRY}

Table 6 reveals that overall per household employment in dairy is 25.55 man-days per year. Employment for landless, marginal, small and medium farmers assimilates 5.89, 29.74, 35.7 and 30.89 man-days per year in dairy every year. Overall man-days is maximum in provide feed and water (5.42). Maximum no. of man-days is small farmers in provide feed and water 7.82 . 
Bebika Dhruw, Reshma Kaushal, Rohit Bhagat, and Narottam Atree

Table 6: Per household employment in Dairy according to no. of farmers (man-days)

\begin{tabular}{|c|c|c|c|c|c|}
\hline Operations & Landless & Marginal & Small & Medium & Overall \\
\hline No. of farmers & 1 & 12 & 7 & 2 & 22 \\
\hline Cleaning of animals & 0.63 & 3.61 & 4.72 & 4.78 & 3.43 \\
\hline Provide feed and water & 1.23 & 7.32 & 7.82 & 5.32 & 5.42 \\
\hline Cleaning of sheds & 0.78 & 3.97 & 4.34 & 4.37 & 3.36 \\
\hline Milking & 1.29 & 4.36 & 4.29 & 3.62 & 3.39 \\
\hline Milk processing & 0 & 0.53 & 2.1 & 1.44 & 1.02 \\
\hline Grazing & 0.93 & 4.54 & 7.38 & 5.51 & 4.59 \\
\hline Marketing & 0 & 2.03 & 2.72 & 3.64 & 2.09 \\
\hline Disposal of dung & 1.03 & 3.38 & 2.33 & 2.21 & 2.23 \\
\hline Total & 5.89 & 29.74 & 35.70 & 30.89 & 25.55 \\
\hline
\end{tabular}

Source: Primary data

Table 7 illustrates the per cent participation of tribal women in dairy operations is 54.05 per cent. Cattle rearing and other major work of related to livestock is being carried out by the tribal women only. No participation of tribal women in grazing and marketing.

Table 7: Participation rate of tribal women in Dairy

\begin{tabular}{|c|c|}
\hline Operations & Per cent \\
\hline Cleaning/brushing of animals & 41.67 \\
\hline Provide feed and water & 75.59 \\
\hline Cleaning of sheds & 100.00 \\
\hline Milking & 32.42 \\
\hline Milk processing & 53.33 \\
\hline Grazing & 0.00 \\
\hline Marketing & 100.00 \\
\hline Total & 54.05 \\
\hline
\end{tabular}

Source: Primary data

\subsection{PER HOUSEHOLD EMPLOYMENT DETAILS IN GOATRY}

Table 8 shows that per household employment in Goatry, 8.41 man-days per year. Employment for marginal, small and medium farmers assimilates $10.38,15.14$ and 9.15 man-days per year in goatry every year.

Table 8: Per household employment in Goatry according to no. of farmers (man-days)

\begin{tabular}{|c|c|c|c|c|c|}
\hline Operations & Landless & Marginal & Small & Medium & Overall \\
\hline No. of farmers & 0 & 7 & 2 & 1 & 10 \\
\hline Cleaning of animals and sheds & 0 & 2.21 & 3.73 & 1.17 & 1.77 \\
\hline Provide feed and water & 0 & 3.23 & 3.19 & 3.03 & 2.36 \\
\hline Disposal of dung & 0 & 1.49 & 1.37 & 1.23 & 1.02 \\
\hline Grazing & 0 & 2.16 & 4.22 & 2.1 & 2.12 \\
\hline Marketing & 0 & 1.29 & 1.36 & 1.3 & 0.99 \\
\hline Milking & 0 & 0 & 0.27 & 0.32 & 0.15 \\
\hline Total & 0 & 10.38 & 15.14 & 9.15 & 8.41 \\
\hline
\end{tabular}

Source: Primary data

Table 9 illustrates the participation percentage of tribal women in Goatry operations is 44.44 per cent. The maximum participation per cent of tribal women has found in disposal of dung operation (100 per cent). No participation of tribal women in grazing, milking and marketing. 
Table 9: Participation rate of tribal women in Goatry

Source: Primary data

\begin{tabular}{|c|c|}
\hline Operations & Per cent \\
\hline Cleaning of animals and sheds & 85.71 \\
\hline Provide feed and water & 71.43 \\
\hline Disposal of dung & 100.00 \\
\hline Grazing & 0.00 \\
\hline Marketing & 0.00 \\
\hline Milking & 0.00 \\
\hline Total & 44.44 \\
\hline
\end{tabular}

\subsection{PER HOUSEHOLD EMPLOYMENT DETAILS IN POULTRY}

Poultry farming can be taken as a part-time occupation especially by women, landless, small and marginal farmers the inputs required for poultry farming are available locally in rural areas. Simple equipments for feeding, watering and sheltering for small units can be manufactured from materials locally available in the villages with the help of local artisans. Land required for starting poultry units is small. Table 10 discusses about the per household employment days in poultry.

Table 10: Per household employment in Poultry according to no. of farmers (man-days)

\begin{tabular}{|c|c|c|c|c|c|}
\hline Operations & Landless & Marginal & Small & Medium & Overall \\
\hline No. of farmers & 0 & 4 & 6 & 2 & 12 \\
\hline Spreading bedding material for cock/hen & 0.00 & 1.39 & 1.63 & 1.92 & 1.23 \\
\hline Cleaning of bedding & 0.00 & 1.74 & 2.58 & 1.70 & 1.50 \\
\hline Provide feed and water & 0.00 & 2.42 & 2.65 & 1.90 & 1.74 \\
\hline Apply pesticide & 0.00 & 0.00 & 0.34 & 0.20 & 0.13 \\
\hline Total & 0.00 & 5.55 & 7.2 & 5.72 & 4.62 \\
\hline
\end{tabular}

Source: Primary data

Study revealed that 4.62 man-days per year involved in poultry employment on a total basis. Marginal, small and medium farmers employed in poultry 5.55, 7.2 and 5.72 man-days per year respectively. Drinking and water management man-days maximum which stands 1.74 man-days per year. In the study area landless farmers have no employment found in poultry.

Table 11 illustrates the participation percentage of tribal women in poultry operations is 46.15 per cent. The maximum participation of tribal women in provide feed \& water (100 per cent) followed by spreading bedding material for cock/hen i.e. 52.38 per cent. In cleaning of bedding, participation per cent of tribal women is 42.85 per cent. Least participation is in application of pesticide 28.57 per cent.

Table 11: Participation rate of tribal women in Poultry

\begin{tabular}{|c|c|}
\hline Operations & Per cent \\
\hline Spreading bedding material for cock/hen & 52.38 \\
\hline Cleaning of bedding & 42.85 \\
\hline Provide feed and water & 100.00 \\
\hline Apply pesticide & 28.57 \\
\hline Marketing & 0.00 \\
\hline Total & 46.15 \\
\hline
\end{tabular}

Source: Primary data 


\subsection{PER HOUSEHOLD EMPLOYMENT DETAILS IN FISHERY}

The table 12 reveals that per household employment details in Fishery. Overall man-days found in fishery are 1.69 man-days per year. Highest man-days found for marketing (0.96) in overall basis.

Table 12: Per household employment in Fishery according to no. of farmers (man-days)

\begin{tabular}{|c|c|c|c|c|c|}
\hline Operations & Landless & Marginal & Small & Medium & Overall \\
\hline No. of farmers & 1 & 2 & 1 & 0 & 4 \\
\hline Supplying feed & 0.62 & 0.89 & 0.93 & 0 & 0.73 \\
\hline Marketing & 1.09 & 1.38 & 1.02 & 0 & 0.96 \\
\hline Total & 1.71 & 2.27 & 1.95 & 0 & 1.69 \\
\hline
\end{tabular}

Source: Primary data

Table 13 illustrates the percentage involvement of tribal women in fisheries is 43.16 per cent. Involvement of tribal women in Provide feed is 47.05 per cent and in marketing operations is 35.19 per cent.

Table 13: Participation rate of tribal women in Fishery

\begin{tabular}{|c|c|}
\hline Operation & Per cent \\
\hline Supplying feed & 47.05 \\
\hline Marketing & 35.19 \\
\hline Total & 43.27 \\
\hline
\end{tabular}

Source: Primary data

Table 14 reveals that the highest overall man-days per year were in agriculture as compared to among all the sectors. Overall man-days per year of farm were 250.07 man-days per year. Second highest man-days are showed in kitchen gardening/vegetable cultivation. The results are in line with the findings of Jaiswal (2018) and K. Suman et al. (2010).

Table 14: Per household employment of Farm (man-days)

\begin{tabular}{|c|c|c|c|c|c|}
\hline Farm sectors & Landless & Marginal & Small & Medium & Overall \\
\hline Agriculture & 103.01 & 244.48 & 225.45 & 186.66 & 189.90 \\
\hline Kitchen gardening/vegetable cultivation & 7.56 & 18.10 & 25.89 & 28.07 & 19.90 \\
\hline Dairy & 5.89 & 29.74 & 35.7 & 30.89 & 25.55 \\
\hline Goatry & 0.00 & 10.38 & 15.14 & 9.15 & 8.41 \\
\hline Poultry & 0.00 & 5.55 & 7.2 & 5.72 & 4.62 \\
\hline Fishery & 1.71 & 2.27 & 1.95 & 0 & 1.69 \\
\hline Total & 118.17 & 310.52 & 311.33 & 260.49 & 250.07 \\
\hline
\end{tabular}

Source: Primary data

It is evident from table 15 that in allied sectors, the highest participation rate of tribal women looked in kitchen gardening having rank $1^{\text {st }}$ along with 77.96 per cent followed by dairy, poultry, goatry, fishery having rank II, III, IV and $\mathrm{V}$ respectively.

Table 15: Participation rate of tribal women in Allied sectors of farm

\begin{tabular}{|c|c|c|}
\hline Allied sectors & Participation per cent & Rank \\
\hline Kitchen gardening & 77.96 & I \\
\hline Dairy & 54.05 & II \\
\hline Poultry & 46.15 & III \\
\hline Goatry & 44.44 & IV \\
\hline Fishery & 43.27 & V \\
\hline
\end{tabular}

Source: Primary data 


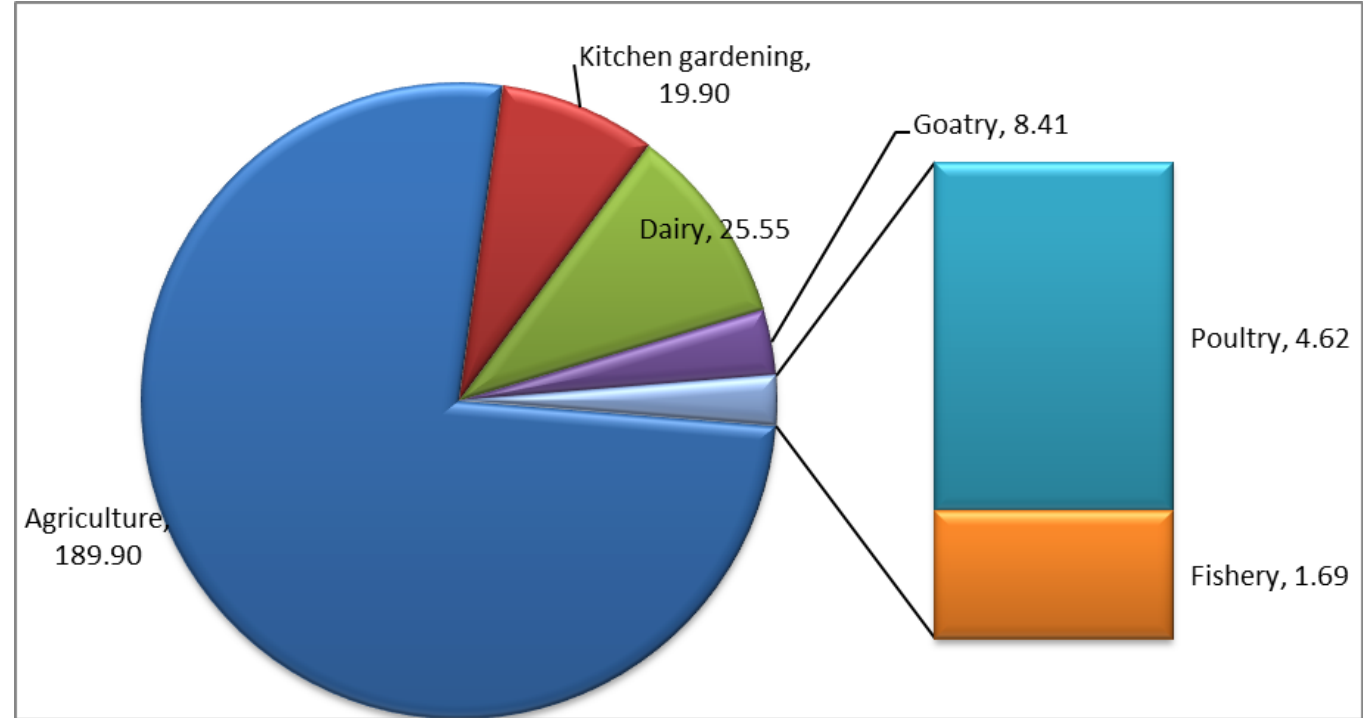

Figure 1: Per household employment of farm (man-days)

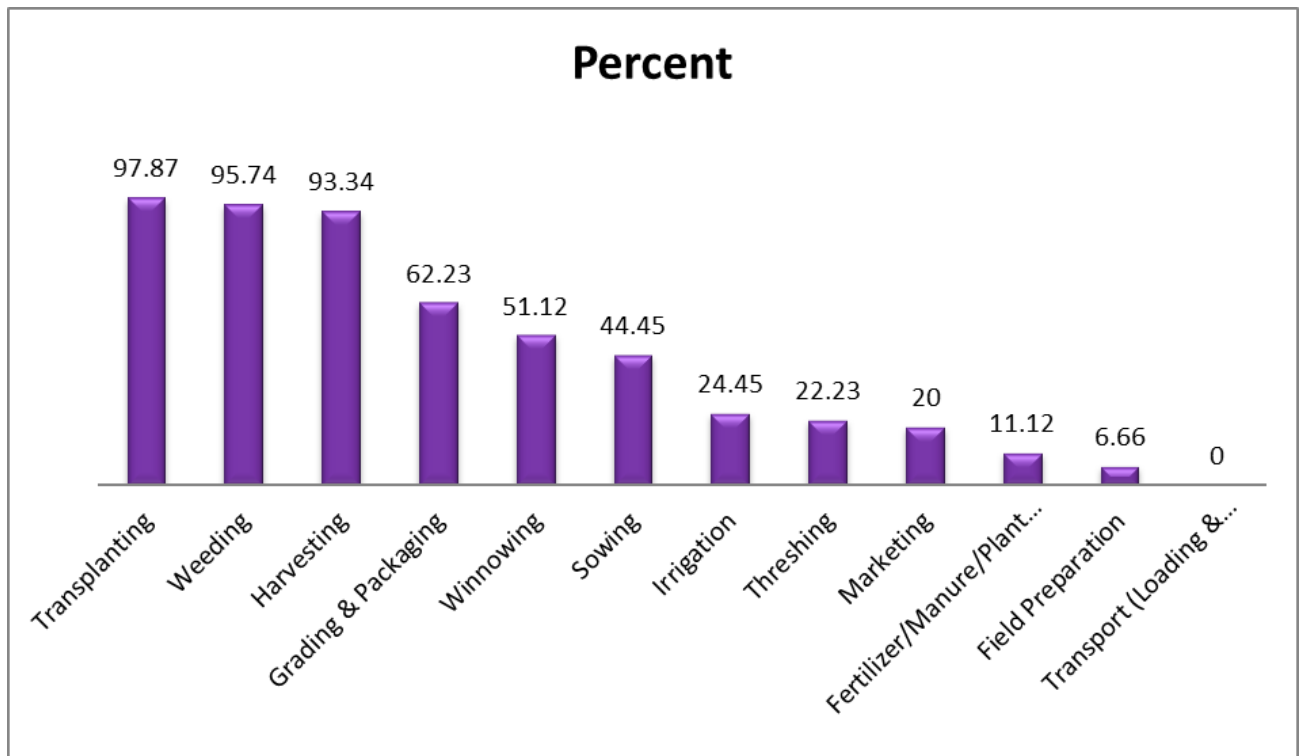

Figure 2: Participation of tribal women in agriculture

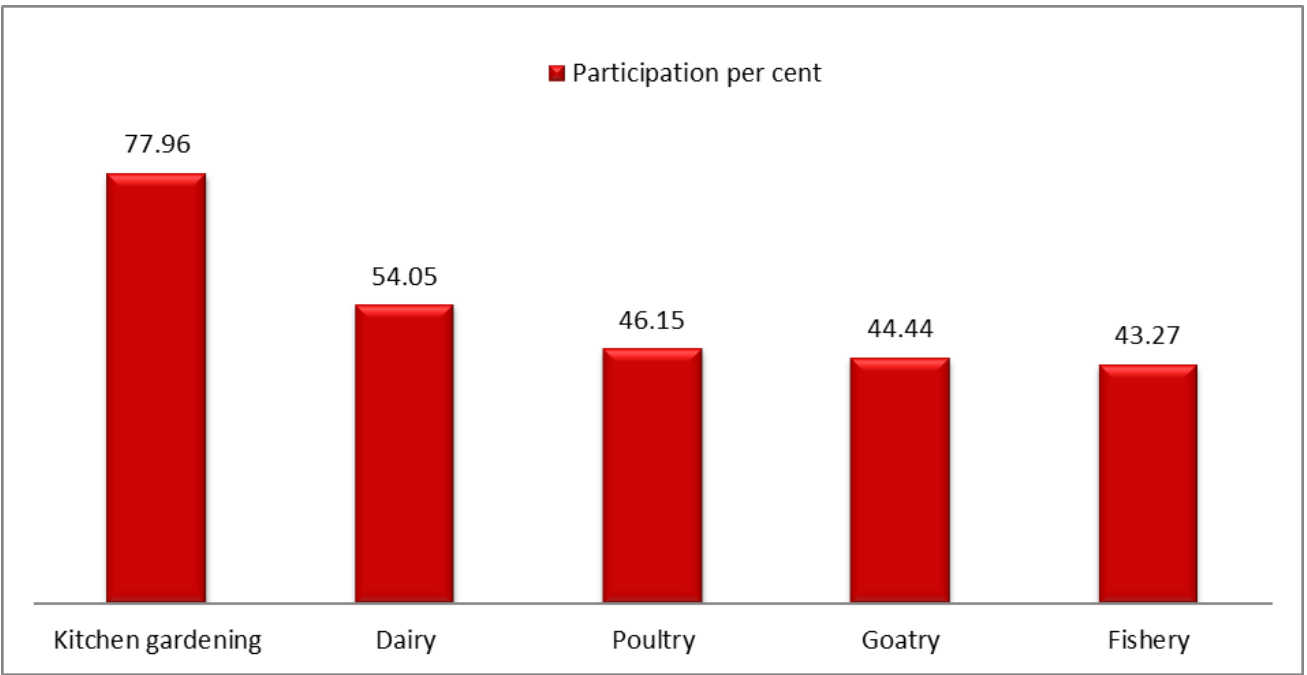

Figure 3: Participation of tribal women in allied sectors of farm 
Bebika Dhruw, Reshma Kaushal, Rohit Bhagat, and Narottam Atree

\subsection{WAGE DISCRIMINATION}

Evident from Table 16 that in the study area overall difference wage between male and female wage rate is ' 22.08 and with difference percentage is 13.95 per cent.

Table 16: Sector wise total wage differentiation with male wage ( / day)

\begin{tabular}{|c|c|c|c|c|}
\hline Sectors & Male wage rate & Female wage rate & Diff. (') & Diff. (\%) \\
\hline Agriculture & 150.00 & 130.00 & -20.00 & 13.33 \\
\hline Kitchen gardening & 150.00 & 130.00 & -20.00 & 13.33 \\
\hline Dairy & 120.00 & 105.00 & -15.00 & 12.50 \\
\hline Goatry & 115.00 & 105.00 & -10.00 & 8.69 \\
\hline Poultry & 125.00 & 110.00 & -15.00 & 12.00 \\
\hline Fish farming & 120.00 & 110.00 & -10.00 & 8.33 \\
\hline Others & 300.00 & 250.00 & -50.00 & 16.67 \\
\hline Overall & 158.27 & 136.19 & -22.08 & -13.95 \\
\hline
\end{tabular}

Difference (Diff.): (+ surplus; - deficit)

It is observed that highest difference between government wage and female wage was found in dairy and goatry sector. The overall difference between female and government wage was `103.48 with 43.17 percentage of difference per cent. Female wage rate has been compared with government wage rate in the other sectors is ` 10.33 profit and with difference percentage is 4.31 per cent.

Table 17: Sector wise wage differentiation ( / day)

\begin{tabular}{|c|c|c|c|c|c|c|c|}
\hline \multirow{2}{*}{ Sectors } & \multirow{2}{*}{ Govt. wage rate } & \multicolumn{3}{|c|}{ Tribal male labour } & \multicolumn{3}{c|}{ Tribal female labour } \\
\cline { 3 - 7 } & & Actual wage (') & $\begin{array}{c}\text { Diff. } \\
()^{\prime}\end{array}$ & $\begin{array}{c}\text { Diff. } \\
(\%)\end{array}$ & Actual wage (') & $\begin{array}{c}\text { Diff. } \\
()^{\prime}\end{array}$ & $\begin{array}{c}\text { Diff. } \\
(\%)\end{array}$ \\
\hline Agriculture & 239.67 & 150.00 & -89.67 & 37.41 & 130.00 & -109.67 & 45.76 \\
\hline Kitchen gardening & 239.67 & 150.00 & -89.67 & 37.41 & 130.00 & -109.67 & 45.76 \\
\hline Dairy & 239.67 & 120.00 & -119.67 & 49.93 & 105.00 & -134.67 & 56.19 \\
\hline Goatry & 239.67 & 115.00 & -124.67 & 52.02 & 105.00 & -134.67 & 56.19 \\
\hline Poultry & 239.67 & 125.00 & -114.67 & 47.84 & 110.00 & -129.67 & 54.10 \\
\hline Fish farming & 239.67 & 120.00 & -119.67 & 49.93 & 110.00 & -129.67 & 54.10 \\
\hline Others & 239.67 & 300.00 & +60.33 & 25.17 & 250.00 & +10.33 & 4.31 \\
\hline Overall & 239.67 & 158.27 & -81.40 & 33.96 & 136.19 & -103.48 & 43.17 \\
\hline
\end{tabular}

Difference (Diff.): (+ surplus; - deficit)

\subsection{CONSTRAINTS FACED}

During the survey, the tribal women reported to following prime constraints in listed on Table 17. The results showed that low wages (73.4 mean score) and less awareness on developmental programmes (66.6 mean score) are the major constraints of tribal women in the surveyed area. lack of education (65.2 mean score), lack of training (59.7 mean score), lack of alternative employments (52.1 mean score), priority for men workers (45.2 mean score), in sufficient credit facility ( 41.3 mean score), lack of freedom to take decision (37.6 mean score), family restrictions (34.6 mean score) and health issues (33.5 mean score) are also other major problems faced by the tribal women. The studies of Jaiswal (2018), Shamna et al. (2018) and Mareeswaran et al. (2017) are also in line with the above findings. The result concludes that the tribal women need to be trained and participate in developmental programmes. This will be help to improve themselves and will also increase their efficiency.

Table 17: Major constraints of tribal women

\begin{tabular}{|c|c|c|c|}
\hline Sr. No & Constraints & Mean score & Rank \\
\hline & Low wages & 73.4 & I \\
\hline
\end{tabular}


Tribal Women Participation in Agriculture and Allied Sectors in Gariaband District of Chhattisgarh

\begin{tabular}{|c|c|c|c|}
\hline & Less awareness on developmental programmes & 66.6 & II \\
\hline & Lack of education & 65.2 & III \\
\hline & Lack of training & 59.7 & IV \\
\hline & Lack of alternate employment & 52.1 & V \\
\hline & Priority for male workers & 45.2 & VI \\
\hline & Insufficient credit facility & 41.3 & VII \\
\hline & Lack of freedom to take decision & 37.6 & VIII \\
\hline & Family restriction & 34.6 & IX \\
\hline & Health issues & 33.5 & $\mathrm{X}$ \\
\hline
\end{tabular}

\section{CONCLUSIONS AND RECOMMENDATIONS}

Tribal women plays a major role in the co-management of their natural, social, economic resources and agricultural development including crop production, livestock production etc. but they remain backward due to illiteracy, superstition, traditional values and many other social and cultural factors. The participatory role of tribal's in improving their living conditions by fully exploring natural endowments and alternative uses must find an appropriate place in the strategic approach. This study reported that the participation of tribal women is high as compared to the tribal men contribution in farm operations. Result of the study shows that tribal women make significant contribution in marginal small and medium sized farm. Overall man-days per year of farm were 250.07 man-days per year for per household tribal farmers. Total percentage contribution of tribal women in agriculture was 56.62 per cent. In agricultural operations, participation of tribal women was found maximum in transplanting with highest participation rate which accounted 97.78 per cent and which holds the rank I followed by weeding (95.56 per cent). In allied sectors the participation of tribal women was maximum in kitchen gardening/vegetable cultivation with highest participation per cent 77.96 and rank position I, followed by dairy and poultry with participation per cent 54.05 \& 46.15 with rank position II \& III respectively. In respect of their active involvement and participation in agriculture and allied sectors, they have not recognized and appreciated. In all the sectors wage differentiation is higher in female wages. Overall female wages are getting ` -103.48 lower than government wage rate with difference percentage of 43.17 per cent. Low wages is the prime constraints in the surveyed area. In general it requires that the support of family members to women in their family life. The tribal women in the study wanted to more and alternative job opportunity for jobless tribal women. Provide adequate information to increase the participation of tribal women in developmental programmes and educational institutions should be established in nearby areas. The government should be focused the empowerment of schedule tribe women and allocate separate funds throughout the five years plan. As per whole the following suggestions are forwarded here to overcome the constraints faced by tribal women in participation of developmental programmes for their livelihood security.

\section{SOURCES OF FUNDING}

This research received no specific grant from any funding agency in the public, commercial, or not-for-profit sectors.

\section{CONFLICT OF INTEREST}

The author have declared that no competing interests exist.

\section{ACKNOWLEDGMENT}

With a deep sense of gratitude and sincerely thanks \& respect to Professors of the Department of Agricultural Economics, Indira Gandhi Krishi Vishwavidyalaya, Raipur, Chhattisgarh for inspiring and excellent guidance, encouragement, unceasing interest, constructive criticism and helping attitude throughout the study. 


\section{REFERENCES}

[1] Gummadi, N. (2014), "Work Participation of Tribal Women in India: A Development Perspective", Journal of Humanities and Social Science, Vol. 19(12), pp. 35-38.

[2] Jayakumar, A. and Palaniyammal, P. (2016), "Socio-Economic Status of Scheduled Tribes in Kalrayan Hills", International Journal of Research- Granthaalayah, Vol. 4(3), pp. 22-30.

[3] Jaiswal, P. (2018), "Female Labour Participation in Agriculture and Allied Sectors in Northern Hills of Chhattisgarh", PhD (Agricultural Economics) Thesis submitted to Department of Agricultural economics, College of Agriculture (Raipur), Indira Gandhi Krishi Vishwavidyalaya, Raipur, Chhattisgarh

[4] Kalyani, K. Suman, Krishnamurthy, V., Rao, C. Chandrashekhar and Kumari, N. Aruna (2010), "Role performance of Tribal women in Agriculture - A study in agency area of East Godavari district, Andhra Pradesh", J. DAIRYING, FOOD \& H.S., Vol. 30(3), pp. 221-224.

[5] Kumar, V., Singh, T.R., Yadav, S.R., and Singh, R.P. (1985), "Employment and Income Pattern of Women Labour in Modern Agriculture in District Meerut (U.P.)”, Indian Journal of Agricultural Economics, Vol. 40(3), pp. 276277.

[6] Mareeswaran, P., Jansirani R., Asokhan M. and Mani K. (2017), "Constraints Faced by Tribal Women in Participation of Developmental Programmes”, International Journal of Agriculture Sciences, Vol. 9, pp. 42574258.

[7] Mohanta, R. (2017), "Participation of Tribal Women in Agriculture", International Journal of Science, Environment and Technology, Vol. 6, pp. 745-750.

[8] Shamna, A., Biswas, P., Jha, S.K. and Kumar, Sh. (2018), "Tribal farm women's participation in Agriculture and factors influencing it: Evidence from West Bengal”, India. J. Agr. Sci. Tech., Vol. 20, pp. 911-922. 